\title{
Factors affecting safety performance on construction sites: An overview
}

\author{
Nour Eldeen M. A. Abo Nassar \\ Civil Engineering Department, Near East University, Nicosia, Via Mersin 10, Turkey
}

\section{ART ICLE INFO}

\section{ARTICLE HISTORY:}

Received: 10 April 2021

Revised: 14 May 2021

Accepted: 17 May 2021

Published: 25 May 2021

\section{KEYWORDS:}

Safety, safety performance, safety management, accidents, construction site

\begin{abstract}
A B S T R A C T
The construction industry is one of the most significant industries that contribute greatly to achieving economic development. However, it is also considered one of the industries that is always exposed to a high risk of hazards in addition to being full of risky activities. Accidents that occurred in construction industries have caused many defects in project progress, for example, delays in completing the project, increasing project cost, reducing productivity, and creating negative impressions about the company. The major reason for the accidents is poor worker safety performance, with a host of contributing causes. For improving safety performance, the root causes of incidents that occur in construction as well as the factors influencing them must be studied. Health and safety issues are the main problem and concerns in the building industry. Though much development has been made in construction safety, the industry still lacks a lag behind most other industries in terms of safety. The aim of this paper is to provide a comprehensive review of the factors that could affect the safety performance of a construction site to reduce the frequency of accidents.
\end{abstract}

\section{INTRODUCTION}

The construction industry mainly contributes to the development process of countries, which leads to an increase in economic growth and consequently, increasing demands for construction activities (Nawi et al., 2017). Although its great importance in the economic development of countries, the building industry also leads to high death rates because of the high rate of accidents (Recarte Suazo \& Jaselskis, 1993).

The construction industry is recognized as the most dangerous industry as it is often accompanied by accidents. These accidents that occurred on building sites lead to many drawbacks in project performance, like delay in completing the project, increasing project cost, reducing productivity, and creating passive perceptions of the organization. Thus, it is important for the worker to make sure that safety and health are taken care of in the workplace to avoid accidents (Abas et al., 2020).

Health and safety issues are extremely significant in all industries and particularly in the building industry. Although the construction industry always faces changes like adapting new methods and new equipment's as well as new machinery, however, it is always running into safety issues, including deaths. Therefore, health and safety problems are always considered important in the construction industry, particularly the problems regarding poor safety performance like injuries and health diseases (Prasad \& Reghunath, 2011).

The remainder of the paper is organized as: in Section 2 the methodology of the study is presented. Information about construction safety management is given in Section 3. Brief information about accidents causes is illustrated in Section 4. Factors affecting safety performance in a construction site is given in Section 5. Finally, the conclusion is presented in Section 6.

\section{METHODOLOGY}

This paper is a review study for the topic of "Factors affecting safety performance at construction projects". Scopus and Google Scholar databases were the major sources for collecting data, as two of the most popular and largest online sources, for high-quality results on the various factors that may impact safety performance in constructions, keywords such as "safety performance", "factors influencing safety performance", or "construction site" were used. 


\section{CONSTRUCTION SAFETY MANAGEMENT}

Safety Management is a process to monitor the policies, procedures and safety practices at the building site (Wilson \& Koehn, 2000). Also, Cheng et al., (2004), stated that it is a dynamic operation that involves little or large modifications applied to site operations to fulfil the required aims without facing unforeseen difficulties to normal business. In addition, safety must be included at every level of the firm and every party in an inter-organizational enterprise. Construction management has to take into account the safety culture and the safety climate as important aspects to be taken care of Flin et al. (2000).

\subsection{Benefits of safety and health in the construction industry}

In general, there are several benefits for safety and health across all industries, and especially in the construction one. The important benefits of safety and health are illustrated in Fig. 1.

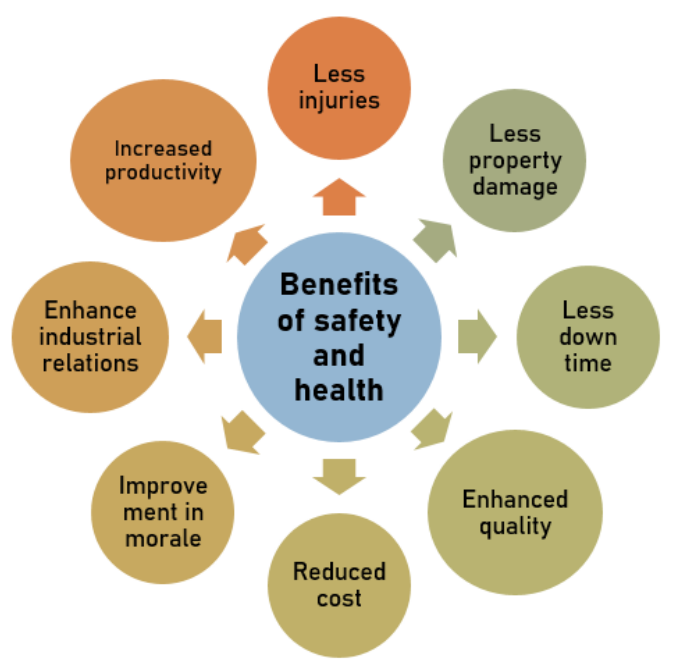

Fig. 1. Benefits of safety and health

\subsection{Safety performance of the construction industry}

In general, negative indicators are often relied on to assess safety performance like the number of accidents, days lost, injuries rate, and accident cost. The significance of safety performance assessment lies in measuring the efficiency of contracting companies' management in preventing accidents by identifying safety goals and purposes (Permana, 2007). In case the project faces high accidents rates, the contractor in question can develop a bad reputation, even though the organization size contributes to the safety performance of the building contractors (Lin \& Mills, 2001). Hence, contractors are obligated to preserve their health and safety reputation through preserving safety performance.

Hinze and Parker (1978) indicated that there is a compatibility between safety performance and high productivity, and it's important not to sacrifice safety to increase productivity. Further, good safety performance relates to the manner of management and putting too much stress on workers by any means leads to an increase in injury rates. Crew productivity might be negatively affected by a worker's injury. For example, a crew who works near an accident will likely work less productively due to the injury. At first, this crew may easily stop operating to monitor activities near the injury. The work crew might be less productive due to a discussion with co-workers about the accident.

\subsection{Safety evaluation methods}

According to the work done by Priyadarshani et al. (2013), Safety Evaluation Methods are illustrated in Table 1.

Table 1. Safety evaluation methods

\begin{tabular}{|l|c|}
\hline $\begin{array}{l}\text { Safety evaluation } \\
\text { method }\end{array}$ & \multicolumn{1}{c|}{ Description } \\
\hline $\begin{array}{l}\text { Applying the } \\
\text { concept of } \\
\text { profiling }\end{array}$ & $\begin{array}{c}\text { This method works by improving } \\
\text { corporate safety performance standards in } \\
\text { a number of categories that customers' } \\
\text { project directors consider important. Then } \\
\text { companies are compared based on these } \\
\text { categories, and then a profile is developed. }\end{array}$ \\
\hline $\begin{array}{l}\text { Perform a safety } \\
\text { audit for an overall } \\
\text { review of the } \\
\text { company's safety } \\
\text { program }\end{array}$ & $\begin{array}{l}\text { A correctly performed safety audit leads to } \\
\text { identify the strength and weakness points } \\
\text { of an existing safety program (Kavianian } \\
\text { \& Wentz, 1990). }\end{array}$ \\
\hline Injury frequency & $\begin{array}{c}\text { It is a method of measuring safety } \\
\text { performance by determining the lost and } \\
\text { injuries numbers per million hrs of } \\
\text { exposure (Jannadi \& Al-Sudairi, 1995). }\end{array}$ \\
\hline
\end{tabular}

Priyadarshani et al. (2013) also mentioned that additional methods have been developed to evaluate the effectiveness of safety management systems at building projects in many countries. For example accidents rate, incidents rate, experience modification rate, and scorecard.

\section{CAUSES OF ACCIDENTS}

These days, because of the frequent accidents at work sites, researchers are often asked to discover fresh methods to improve and enhance safety performance in constructions. Moreover, both direct and indirect accidents cost add more expenses to building projects due to improper safety performance in building sites. Approximately $99 \%$ of these accidents are caused by unsafe actions, unsafe conditions, or both (Charehzehi \& Ahankoob, 2012). For 
improving safety performance, the causes of construction accidents must be investigated. The main reasons for accidents in construction are shown in Fig. 2.

Pipitsupaphol and Watanabe (2000), stated that the type of equipment's and machinery, site condition, industry nature, attitude and the way of management could directly influence safety performance in the building industry. Moreover, working at high elevations, inadequate safety devices, mismanagement, lack of obedience in site, neglect of workers, and the employment of unskilled employees are common in the building industry which increases the risk of accidents and causes damage and injuries.

Kartam et al. (2000) indicated that the reasons for the accident are worker turnover and incorrect action, deficiency in safety performance, inappropriate or unclean materials, unregulated work, poor record-keeping of accidents, lack of maintenance tools, and poor supervision and inspection.

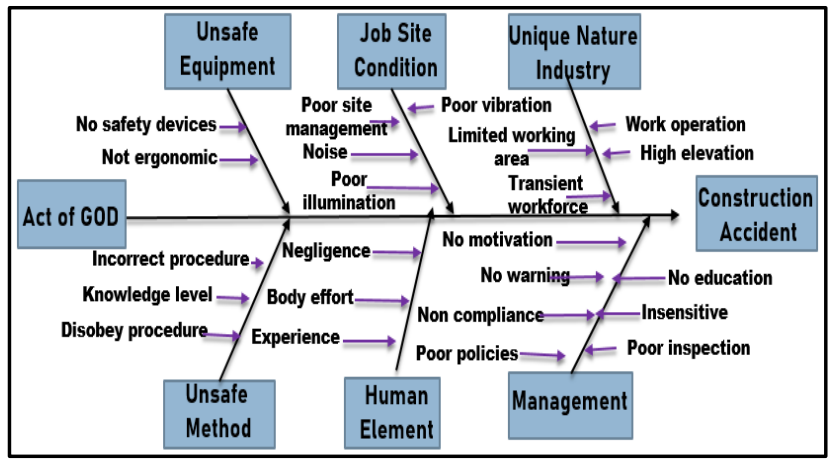

Fig. 2. Causes of construction accidents (Hamid et al., 2008)

\subsection{Safety training importance}

Training plays a significant part in determining management practices to improve safety performance. Offering regular training courses increases employee knowledge about dangerous tasks. Further, safety training is very beneficial since it permits workers to foresee future accidents or imminent accidents (Charehzehi \& Ahankoob, 2012).

As Paringga (2010), stated that training is made to avoid human errors which could be the reason for accidents as well as to allow workers to do a repetitive tasks skillfully. Lai et al. (2011), also mentioned that safety training is a very efficient way of mitigating risks because the training improves the skills of workers and their ability to identify risks.

Regular safety training sessions with supervisors, managers, and employees are also important in encouraging employees to apply the safety concept in the organization. Appropriate safety training improves employee safety knowledge and experience and develops positive safety behaviours and attitudes (Tam et al., 2004).

\section{FACTORS INFLUENCING SAFETY PERFORMANCE OF CONSTRUCTION SITES}

According to Shah et al. (2015) and Enshassi et al. (2009), there are many factors that could be categorized into 9 different major groups as follows:

\subsection{Cost factors}

Cost is the most considerable factor affecting any industry if it is construction or manufacturing. The major factors included in the cost group are prices escalation of material, project cash flow, materials cost, equipment's cost, project labour cost etc.

\subsection{Time factors}

Time is directly correlated to the performance of construction. Some of the time factors include average delay due to closure, lack of materials, project duration, the average delay in payments to the contractor, the ratio of orders delivered late, the time required to correct defects, time of site preparation and time required to execute change orders.

\subsection{Quality factors}

Quality is one of the important measures for the customer side. High-quality construction required a high amount of time to construct the amenities.

\subsection{Productivity factors}

depend on labour, skilled personal and semi-skilled personal. So the productivity is influenced by labour and so on performance too.

\subsection{Client satisfaction factors}

Client Satisfaction also affecting the performance of construction. Coordination of information between owner and project parties affecting client satisfaction.

\subsection{Government policies}

Government policies affect the speed of construction as well completion of construction. The viewpoint of the contractor is also important.

\subsection{Health and safety factors}

This group contain four cofactors; reportable accident rate, applications of health and safety factors in a company, assurance rate of projects, and ease of arrival to the site (project site). 


\subsection{Innovation and learning factors}

The innovation and learning factor also affects construction performance. Four factors are mainly included, namely learning from own experiences and history, training of human resources in the skills required by the project, reviewing and resolving failures, and learning from the best practices and experiences of others

\subsection{Surrounding circumstances}

The environment is also an important aspect of the human body. It affects the productivity of construction as well as the performance of construction. Major factors are climate condition in the site, noise level, air quality, and waste around the site.

Table 2. Factors affecting safety performance

\begin{tabular}{|c|c|c|}
\hline Authors & Factors affecting safety performance & Factors' Group \\
\hline Enshassi et al. (2009) & $\begin{array}{l}\text { - } \quad \text { Cash flow of the project, } \\
\text { - } \quad \text { Site preparation time, } \\
\text { - } \quad \text { Quality training/meeting, } \\
\text { - } \quad \text { Project complexity, } \\
\text { - } \quad \text { Emplo condition problems, } \\
\text { - } \quad \text { Reportable accidents rate in a project, } \\
\text { - } \quad \text { Noise level, climate condition, wastes around the site. }\end{array}$ & $\begin{array}{l}\text { Cost factor, } \\
\text { Time factor, } \\
\text { Quality factor, } \\
\text { Productivity factor, } \\
\text { Environmental factor, } \\
\text { People factor, } \\
\text { Health and safety factor, } \\
\text { Environmental factor. }\end{array}$ \\
\hline Saraf (2013) & $\begin{array}{l}\text { - Improper planning, } \\
\text { - } \quad \text { Decision making, } \\
\text { - } \quad \text { Shoductivity, } \\
\text { - } \quad \text { Site management, } \\
\text { - The complexity of the project, } \\
\text { - Client's Satisfaction. }\end{array}$ & $\begin{array}{l}\text { Productivity/time factor, } \\
\text { Cost factor, } \\
\text { Productivity factor, } \\
\text { Quality factor, } \\
\text { Productivity factor, } \\
\text { Productivity factor, } \\
\text { Client satisfaction. }\end{array}$ \\
\hline Juliet and Ruth (2014) & $\begin{array}{l}\text { - Raw materials and equipment's quality, } \\
\text { - The planned time for building the project, } \\
\text { - Cost of material and equipment, } \\
\text { - Learning from best practices and experiences of others, } \\
\text { - Climate condition. }\end{array}$ & $\begin{array}{l}\text { Quality factor, } \\
\text { Time factor, } \\
\text { Cost factor, } \\
\text { Innovation and learning factor, } \\
\text { Environmental factor. }\end{array}$ \\
\hline Wong and Soo (2019) & $\begin{array}{l}\text { - } \quad \text { personal protective equipment, } \\
\text { - } \quad \text { Government role, } \\
\text { - } \quad \text { Tracaining, } \\
\text { - } \quad \text { Contingency planning and preparedness. } \\
\end{array}$ & $\begin{array}{l}\text { Productivity factor, } \\
\text { Government factor, } \\
\text { Quality factor, } \\
\text { Quality factor, } \\
\text { Health and safety. }\end{array}$ \\
\hline Bitamba and An (2020) & $\begin{array}{l}\text { - } \quad \text { Experience and skill, } \\
\text { - } \quad \text { Delays in payments, } \\
\text { - } \quad \text { The complexity of the project. } \\
\end{array}$ & $\begin{array}{l}\text { Quality factor, } \\
\text { Time factor, } \\
\text { Productivity factor. }\end{array}$ \\
\hline Mosly (2020) & $\begin{array}{l}\text { - Healthy work environment, } \\
\text { - } \quad \text { Provide the site with the necessary safety measures, } \\
\text { - } \quad \text { Provision of equipment and places that protect workers } \\
\text { - } \quad \text { Phd make them more comfortable, } \\
\text { - } \quad \text { Prevent fire, } \\
\text { - } \quad \text { Suitability of the workers, } \\
\text { - } \quad \text { Characteristics of the project. }\end{array}$ & $\begin{array}{l}\text { Health and safety factor, } \\
\text { Productivity factor, } \\
\text { Health and safety factor. } \\
\text { Productivity factor. } \\
\text { Productivity factor, } \\
\text { Health and safety factor, } \\
\text { Quality/people factor, } \\
\text { Cost/Time factor. }\end{array}$ \\
\hline $\begin{array}{l}\text { Usukhbayar and Choi } \\
\text { (2020). }\end{array}$ & $\begin{array}{l}\text { - } \quad \text { Fail of wearing personal protective equipment's, } \\
\text { - } \quad \text { Use of defective or improper ladders, } \\
\text { - } \quad \text { Defective pieces of equipment and machines. }\end{array}$ & $\begin{array}{l}\text { Innovation \& learning factor, } \\
\text { Quality factor, } \\
\text { Quality factor. }\end{array}$ \\
\hline
\end{tabular}

Moreover, several articles have examined the factors that impact the performance of constructions in a number of ways. Some of the studies identified the most important factors in several countries and various project types, while other studies focused on the impact of the factors on the success and failure of building sites, and suggest ways to enhance and decrease their impact on building projects. Table 2 illustrates the most frequent factors that influence safety performance in building sites. 


\section{CONCLUSION}

In conclusion, by reviewing the literature, several factors have been identified that can influence the safety performance of a construction site, all of these factors should be well investigated and studied in order to reduce accident rates on construction sites. In addition to that, more focus has to be placed on continuous training, because it increases the skills of workers and gives them an adequate understanding of safety importance.

Appropriate safety training improves employee safety knowledge, experience, and develops positive safety behaviours and attitudes.

\section{REFERENCES}

[1] Abas, N. H., Yusuf, N., Suhaini, N. A., Kariya, N., Mohammad, H., \& Hasmori, M. F. (2020). Factors Affecting Safety Performance of Construction Projects: A Literature Review. IOP Conference Series: Materials Science and Engineering, 713(1), p. 012036. https://www.doi.org/10.1088/1757899X/713/1/012036

[2] Bitamba, B. F., \& An, S. H. (2020). Study on factors affecting the performance of construction projects in the Democratic Republic of the Congo. South African Journal of Industrial Engineering, 31(1), 12-25. http://dx.doi.org/10.7166/31-1-2193

[3] Charehzehi, A., \& Ahankoob, A. (2012). Enhancement of safety performance at construction site. International Journal of Advances in Engineering \& Technology, 5(1), 303-312.

[4] Cheng, E. W., Li, H., Fang, D. P., \& Xie, F. (2004). Construction safety management: an exploratory study from China. Construction Innovation, 4(4), 229-241. https://doi.org/10.1108/14714170410815114

[5] Enshassi, A., Mohamed, S., \& Abushaban, S. (2009). Factors affecting the performance of construction projects in the Gaza strip. Journal of Civil engineering and Management, 15(3), 269-280. https://doi.org/10.3846/1392-3730.2009.15.269-280

[6] Flin, R., Mearns, K., O'Connor, P., \& Bryden, R. (2000). Measuring safety climate: identifying the common features. Safety science, 34(1-3), 177-192. https://doi.org/10.1016/S0925-7535(00)00012-6

[7] Hamid, A. R. A., Majid, M. Z. A., \& Singh, B. (2008). Causes of accidents at construction sites. Malaysian journal of civil engineering, 20(2), 242-259.

[8] Hinze, J., \& Parker, H. W. (1978). Safety: productivity and job pressures. Journal of the Construction Division, 104(1), 27-34. https://doi.org/10.1061/JCCEAZ.0000754

[9] Jannadi, M. O., \& Al-Sudairi, A. (1995). Safety management in the construction industry in Saudi Arabia: Survey shows that level of company practice influences safety performance. Building research and information, 23(1), 60-63.

https://doi.org/10.1080/09613219508727425

[10] Juliet, M. E., \& Ruth, O. E. (2014). An evaluation of factors affecting the performance of construction projects in Niger state. Journal of Environmental Sciences and Resources Management, 6(1), 34-43.

[11] Kartam, N. A., Flood, I., \& Koushki, P. (2000). Construction safety in Kuwait: issues, procedures, problems, and recommendations. Safety Science, 36(3), 163-184. https://doi.org/10.1016/S0925-7535(00)00041-2

[12] Kavianian, H.R. and Wentz, C.A. (1990). Occupational and Environmental Safety Engineering and Management. New York: Van Nostrand Reinhold.

[13] Lai, D. N., Liu, M., \& Ling, F. Y. (2011). A comparative study on adopting human resource practices for safety management on construction projects in the United States and Singapore. International Journal of Project Management, 29(8), 1018-1032. https://doi.org/10.1016/j.ijproman.2010.11.004

[14] Lin, J., \& Mills, A. (2001). Measuring the occupational health and safety performance of construction companies in Australia. Facilities, 19(3/4), 131-139. https://doi.org/10.1108/02632770110381676

[15] Mosly, I. (2020). Factors influencing safety performance in the construction industry of Saudi Arabia: an exploratory factor analysis. International journal of occupational safety and ergonomics, 1-8. https://doi.org/10.1080/10803548.2020.1838774

[16] Nawi, M. N. M., Ibrahim, S. H., Affandi, R., Rosli, N. A., \& Basri, F. M. (2017). Factor affecting safety performance construction industry. International Review of Management and Marketing, 6(8S), 280285.

[17] Paringga, L. A. (2010). Construction Safety in Jakarta, Indonesia. [Doctoral dissertation, Universiti Teknologi Malaysia].

[18] Permana, I. E. (2007). Construction safety practices in Batam, Indonesia. [Master Thesis, Universiti Teknologi Malaysia].

[19] Pipitsupaphol, T., \& Watanabe, T. (2000). Identification of root causes of labor accidents in the Thai construction industry. Proceedings of the 4th Asia Pacific structural engineering and construction conference (APSEC 2000), 13-15.

[20] Prasad, R. S. V. S. \& Reghunath, K. P. (2011). Evaluation of safety performance in a construction organization in India: a study. International Scholarly Research Notices, 2011, 1-6. https://doi.org/10.5402/2011/276545

[21] Priyadarshani, K., Karunasena, G., \& Jayasuriya, S. (2013). Construction safety assessment framework for developing countries: a case study of Sri Lanka. 
Journal of Construction in Developing Countries, 18(1), 33-51.

[22] Saraf, D. D. (2013). Study of factors affecting performance of construction project. International Journal of Science and Research, 14(5), 2319-7064.

[23] Shah, G. S., Pitroda, J. R., \& Bhavsar, J. J. (2015). A Critical Literature Review on Integrated Framework for Assessing Factors Affecting Construction Performance, International Journal of Furturistic Trends in Engineering and Technology, 3(1), 9-14.

[24] Recarte Suazo, G. A., \& Jaselskis, E. J. (1993). Comparison of construction safety codes in United States and Honduras. Journal of construction engineering and management, 119(3), 560-572. https://doi.org/10.1061/(ASCE)07339364(1993)119:3(560)

[25] Tam, C. M., Zeng, S. X., \& Deng, Z. M. (2004). Identifying elements of poor construction safety management in China. Safety science, 42(7), 569-586. https://doi.org/10.1016/j.ssci.2003.09.001

[26] Usukhbayar, R., \& Choi, J. (2020). Critical safety factors influencing on the safety performance of construction projects in Mongolia. Journal of Asian Architecture and Building Engineering, 19(6), 600612.

https://doi.org/10.1080/13467581.2020.1770095

[27] Wilson, J. M., \& Koehn, E. E. (2000). Safety management: problems encountered and recommended solutions. Journal of construction engineering and management, 126(1), 77-79.

https://www.doi.org/10.1061/(ASCE)07339364(2000)126:1(77)

[28] Wong, S. S., \& Soo, A. L. (2019). Factors influencing safety performance in the construction industry. $e$ Bangi, 16(3), 1-9. 